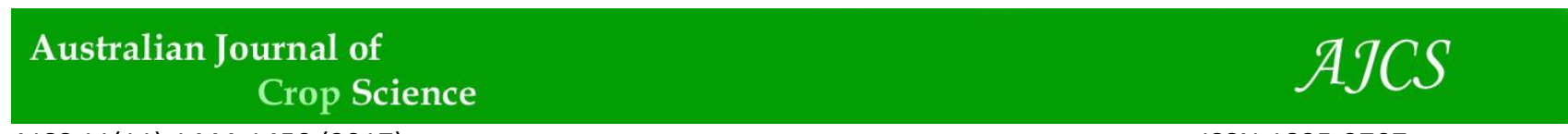

AJCS 11(11):1444-1450 (2017)

ISSN:1835-2707

doi: 10.21475/ajcs.17.11.11.pne574

\title{
Agronomic and economic efficiency of fertilization of broccoli (Brassica oleracea var. Avenger) with boron (B) and poultry litter
}

\author{
Rodrigo Teles Mendes ${ }^{1}$, Rafael Umbelino Bento ${ }^{1}$, Ricardo Felício ${ }^{1}$, João Antônio Gonçalves e Silva ${ }^{1}$, \\ Cleiton Gredson Sabin Benett ${ }^{1,2}$ and Adilson Pelá ${ }^{1 *}$
}

\author{
${ }^{1}$ Goiás State University (UEG), Rodovia GO 330, km 241, Anel Viário, Setor Universitário, 75780-000, Ipameri \\ Campus, Goiás, Brazil \\ ${ }^{2}$ Faculty member of the Professional Master's Program in Conservation of Natural Resources of the Federal \\ Institute Cerrado Goiano Campus Urutaí. Urutaí-GO, Brazil
}

*Corresponding author: adilson.pela@ueg.br

\begin{abstract}
The aim of the study was to evaluate the agronomic and economic characteristics of broccoli following the application of boron (B) doses in the transplanting furrow with or without the application of poultry litter. The research was carried out in a Dystrophic RedYellow Latosol (Oxisol) from April to July 2015. The experimental design was randomized blocks in a 2 x 5 factorial arrangement, where the first factor was fertilization without or with poultry litter $\left(0\right.$ and $\left.10 \mathrm{t} \mathrm{ha}^{-1}\right)$ and the second factor was the $\mathrm{B}$ dose $(0,2,4,6$ and $8 \mathrm{~kg} \mathrm{ha}^{-1}$ ), with three replicates. The broccoli cultivar used was the Avenger hybrid. The analyzed variables were B content in the inflorescence, leaves, and stem; total B content of the shoot; fresh and dry mass of the inflorescence, leaves and stem; inflorescence diameter; total and commercial yields; incidence of hollow stem; and economic aspects of fertilization. The poultry litter, on the average of all doses, increased the foliar B levels and the fresh mass of the broccoli inflorescences and leaves, providing a greater yield and gross revenue. The B levels in the inflorescences and leaves increased with the B dose regardless of fertilization with poultry litter but only increased in the absence of the organic fertilizer in the stems. The profitability index increased with the B dose up to $8 \mathrm{~kg} \mathrm{ha}^{-1}$ in both the presence and absence of fertilization with poultry litter, but the more appropriate to farmers was the B dose of $8 \mathrm{~kg} \mathrm{ha}^{-1}$ and $10 \mathrm{tha}^{-1}$ of poultry litter.
\end{abstract}

Keywords: Brassica oleracea, micronutrient, profitability index.

Abbreviations: DAT_days after transplanting; GR_ gross revenue; GR-C_gross revenue - B application costs; PI_profitability index; IDM_inflorescence dry mass; SFM_stem fresh mass; SDM_stem dry mass; ID_inflorescence diameter; OHS_occurrence of hollow stem; IFM_inflorescence fresh mass; LFM_leaf fresh mass

\section{Introduction}

Broccoli (Brassica oleracea) is a vegetable grown in various regions of the world; it is recognized for its nutritional value and is rich in nutrients and low in calories. The part of the broccoli plant that is usually consumed is the inflorescence, which can be of the sprouting or single head type. Broccoli is both commercialized fresh and processed (Lalla et al., 2010). This plant is sensitive to low levels of boron (B) and may present B deficiency in soils not subjected to B correction (Souza and Resende, 2003). Boron deficiencies can also occur in sandy soils, which are poor in organic matter and acids. Thus, B fertilization is frequently recommended in Brazilian soils (Bergamin et al., 2005), especially in cerrado (Brazilian savanna) soils (Capone et al., 2016).

The range between $\mathrm{B}$ deficiency and toxicity in plants is narrow (Gupta, 1983). Application in excess can become toxic, causing burns on the edges of the leaves, a decrease in plant growth and even plant death (Nable et al., 1997). Boron deficiency in broccoli can result in darkening of the central part of the stem, small and little compact inflorescences and the occurrence of hollow stem disorder (Filgueira, 2013).

In the soil, B is mainly bound to organic matter in the form of organic B, which is a readily available source of B for plants. Boron has good availability in soils that receive abundant organic fertilization or are rich in organic matter, demonstrating protection of the released nutrient against profile leaching; however, little evidence of B being adsorbed by humus is available (Kiehl, 2010).

Among the most common organic fertilizers, poultry litter stands out because it is a good source of nutrients (Blum et al., 2003) and is easily acquired in regions near poultry farms. When properly managed, poultry litter can partially or fully replace chemical fertilizers (Blum et al., 2003).

The material used as litter, the particle size, the number of batches and the production system define the decomposition rate and levels of nutrients, including $\mathrm{B}$, present in the poultry litter (Kiehl, 2010). In the specific case of this nutrient, Valadão et al. (2011) found a B content of $137 \mathrm{mg}$ $\mathrm{kg}^{-1}$ total B in the dry matter. No reports were found on the influence of organic fertilization with poultry litter on the availability of B in broccoli crops. However, some studies have demonstrated its importance in other vegetables.

In the work by Mueller et al. (2013), fertilization with poultry litter increased the leaf B content in tomatoes. In studies with cabbage, Bergamin et al. (2005) observed increase in the production and boron content in the soil with the application of cattle manure vermicompost. Carneiro et 
al. (1995) applied B doses in the absence of organic matter and obtained a cabbage yield of $38.78 \mathrm{t} \mathrm{ha}^{-1}$; the doses fit a quadratic regression, with a maximum point of $2.2 \mathrm{~kg} \mathrm{ha}^{-1} \mathrm{~B}$. This result shows the importance of evaluating the response of crops to B while simultaneously considering the use of organic fertilizers.

The goal of the experiment was to evaluate the agronomic and economic characteristics of broccoli crops following the application of B doses in soil with or without the application of poultry litter.

\section{Results and Discussion}

\section{Biomass components and production}

The application of poultry litter provided an increase in the inflorescence fresh mass (IFM) of $0.09 \mathrm{~kg} \mathrm{plant}^{-1}$ compared to the treatment without poultry litter for the average B dose (Table 1). All plants harvested in the experiment reached the commercial standard according to the classification standards and visual aspects used for cauliflower, which were adopted to classify broccoli (Hortibrasil, 2015). A significant difference in the leaf fresh mass (LFM) was also observed after the application of poultry litter, with a $1.89 \mathrm{~kg} \mathrm{plant}^{-1}$ and $9.5 \%$ increase relative to the treatment without the poultry litter application, although a significant difference was not observed for the different $\mathrm{B}$ doses. There was no significant effect of the organic fertilization or the B dose on the inflorescence dry mass (IDM), stem fresh mass (SFM), stem dry mass (SDM), inflorescence diameter (ID), and occurrence of hollow stem (OHS).

These increases in LFM and IFM may be related to the additional nutrients, improvements in the physical soil conditions and the higher water retention and absorption by the plants provided by the poultry litter. In this study, the IFM was higher than the IFM obtained by Melo et al. (2010), who worked with different varieties of broccoli and obtained a maximum average mass of $0.46 \mathrm{~kg}$ per inflorescence. Pizetta et al. (2005) also obtained greater IFM values that the values obtained here using $B$ doses up to $8 \mathrm{~kg} \mathrm{ha}^{-1}$ in the soil. The ID determination is essential for commercialization. Ceagesp (2016) showed that the best prices were obtained for inflorescences with diameters between 15 and $24 \mathrm{~cm}$. Therefore, all inflorescences regardless of the organic fertilization or the B dose presented IDs within the optimal range (between 17.89 and $18.27 \mathrm{~cm}$ ) (Table 1).

The OHS was high in all treatments, with frequencies of 87 to $100 \%$ of the plants evaluated (Table 1). These results demonstrate that the $\mathrm{B}$ doses used and the poultry litter application were not sufficient to decrease the occurrence of this physiological disorder. Factors other than the addition of $\mathrm{B}$, such as genetic or environmental factors, may have been responsible for the problem. According to Campagnol et al. (2009), this disorder may develop as a result of physiology related to the mobility of the element in the plant even in soils with high B levels. Different results were obtained by Camargo et al. (2009), who reported a reduced occurrence of hollow stem disorder in cauliflower when B doses up to $8 \mathrm{~kg}$ $\mathrm{ha}^{-1}$ were used.

The application of $10 \mathrm{t} \mathrm{ha}^{-1}$ of poultry litter increased the B content in the broccoli leaves for the average B dose, surpassing the treatments without poultry litter by $20.6 \%$ (Table 2). However, there was no significant difference in the $\mathrm{B}$ levels in the inflorescences, with average levels of 63.47 and $66.46 \mathrm{mg} \mathrm{kg}^{-1} \mathrm{~B}$, nor in the stem, with average B doses of 70.6 and $72.2 \mathrm{mg} \mathrm{kg}^{-1}$ (Table 2).
The $\mathrm{B}$ doses promoted increases in the $\mathrm{B}$ levels in the inflorescences and leaves, with significant linear trends. In the leaves, the $\mathrm{B}$ content was $90.66 \mathrm{mg} \mathrm{kg}^{-1}$ without poultry litter and $8 \mathrm{~kg} \mathrm{ha}^{-1} \mathrm{~B}$ (Fig 1a). With the $8 \mathrm{~kg} \mathrm{ha}^{-1} \mathrm{~B}$ and poultry litter, was obtained $114.91 \mathrm{mg} \mathrm{kg}^{-1}$, represented a 90\% increase relative to the control treatment (Fig 1b). With the $8 \mathrm{~kg} \mathrm{ha}^{-1} \mathrm{~B}$, was obtained in the inflorescence $77.32 \mathrm{mg}$ $\mathrm{kg}^{-1} \mathrm{~B}$ (Fig 2a). With the $8 \mathrm{~kg} \mathrm{ha}^{-1} \mathrm{~B}$ dose and $10 \mathrm{Mg} \mathrm{ha}^{-1}$ of poultry litter, $75.93 \mathrm{mg} \mathrm{kg}^{-1} \mathrm{~B}$ was obtained in the inflorescence, which was $48.9 \%$ higher than the value obtained in the control treatment (Fig 2b). These results characterize a luxury consumption of the nutrient by the plant because only the B levels increased with the doses and not the IFM, IDM, ID, LFM and LDM. These levels were not sufficient to cause toxicity.

A significant interaction was detected between poultry litter and the B dose in the soil, with a linear trend observed for the $\mathrm{B}$ content in the stem without the application of poultry litter (Fig 3). A greater B content in the stem was obtained with the $8 \mathrm{~kg} \mathrm{ha}^{-1}$ dose with $96.93 \mathrm{mg} \mathrm{kg}^{-1} \mathrm{~B}$ in the stem dry matter, which was $54 \%$ higher than the control. The application of poultry litter did not result in a significant difference in the B dose in the soil, with values ranging from 57.66 to $80.33 \mathrm{mg}$ $\mathrm{kg}^{-1} \mathrm{~B}$ in the dry matter.

The use of the largest $\mathrm{B}$ dose in the experiment promoted an increase in the B levels above the levels considered adequate without any visible signs of toxicity in the plants. The largest B levels were found in the leaves. This phenomenon may have occurred because B does not move in the phloem; instead, its transport is accomplished via the xylem, which primarily directs this element to sites with greater transpiration (leaves) instead of the sites with a greater demand for $\mathrm{B}$, such as the inflorescences and stem (Compagnol et al., 2009).

Pizetta et al. (2005) worked with doses up to $8 \mathrm{~kg} \mathrm{ha}^{-1} \mathrm{~B}$ in cabbage in sandy soil and also observed an increasing linear trend for the foliar B levels, which ranged between 33 and 81 $\mathrm{mg} \mathrm{kg}^{-1}$ as a function of the B doses. However, Bergamin et al. (2005) and Compagnol et al. (2009) found no significant differences in the foliar B levels in the cabbage crop with the application of $\mathrm{B}$ and cattle vermicompost.

The application of $10 \mathrm{t} \mathrm{ha}^{-1}$ of poultry litter resulted in a yield of $21730 \mathrm{~kg} \mathrm{ha}^{-1}$ and an increase of $8.5 \%$ relative to the treatments without poultry litter. However, no significant difference in the yield occurred with the increased $\mathrm{B}$ doses (Table 3). This result may have occurred because the poultry litter met the need for B by the plants at the smaller B doses, as $2 \mathrm{~kg} \mathrm{ha}^{-1}$ was added with the poultry litter. According to Rosolém and Bíscaro (2007), most of the B available in the soil is strongly bound to the organic fraction.

Similar results were obtained by Bergamin et al. (2005), who also found no interaction between the $\mathrm{B}$ dose and $10 \mathrm{t}$ $\mathrm{ha}^{-1}$ vermicompost in cabbage. In contrast, Carneiro et al. (1995) applied B doses in the absence of organic fertilization and obtained quadratic regression for the production of cabbage, with a maximum point of $2.2 \mathrm{~kg} \mathrm{ha}^{-1} \mathrm{~B}$.

\section{Economic efficiency}

The gross revenue (GR) was higher with the use of $10 \mathrm{t} \mathrm{ha}^{-1}$ poultry litter at US $\$ 13,221.05$, representing an increase of US $\$ 1,184.25$ relative to the control treatment (Table 3). When the cost of the poultry litter and B applications (GR-C) was removed, no significant difference was detected between the treatments, which had average revenues of US\$11,984.01 to US\$12,812.40. 
Table 1. Inflorescence fresh and dry mass (IFM and IDM), leaf fresh and dry mass (LFM and LDM), stem fresh and dry mass (SFM and SDM), inflorescence diameter (ID) and occurrence of hollow stems (OHS) in the broccoli crop. Ipameri-GO, 2016.

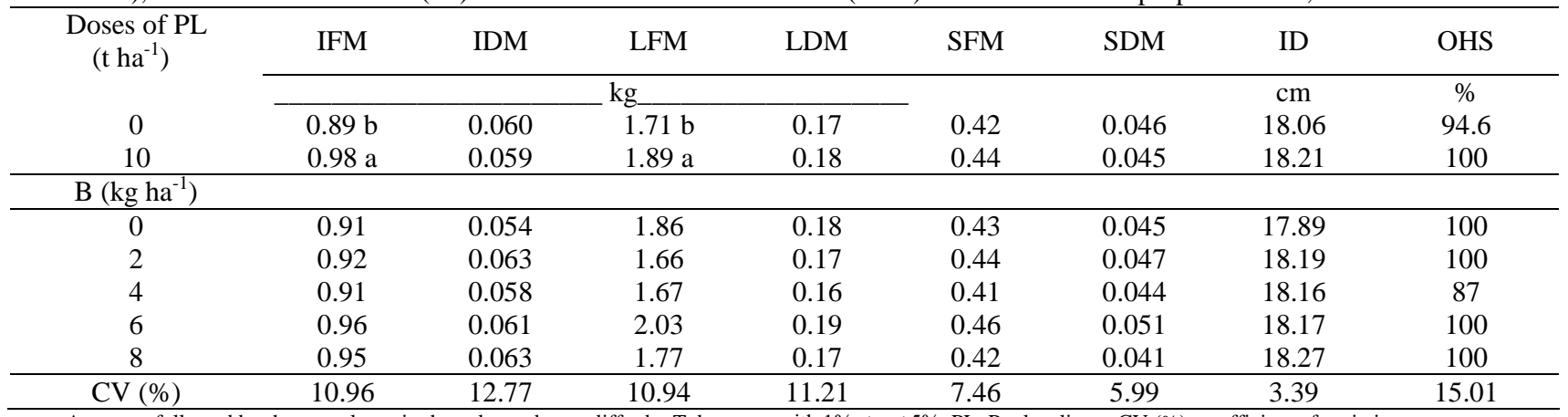

Averages followed by the same letter in the column do not differ by Tukey test, with $1 \% \leq \mathrm{p} \leq 5 \%$. PL: Poultry litter. CV (\%): coefficient of variation

(a)

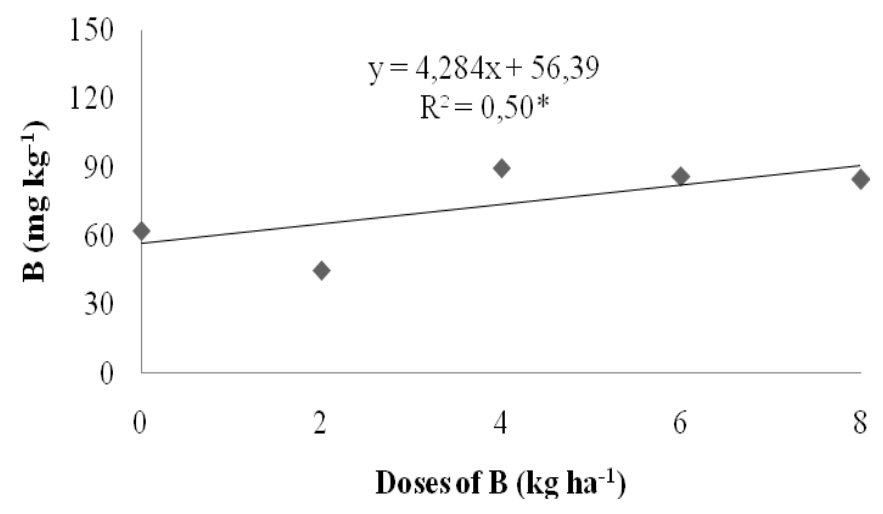

(b)

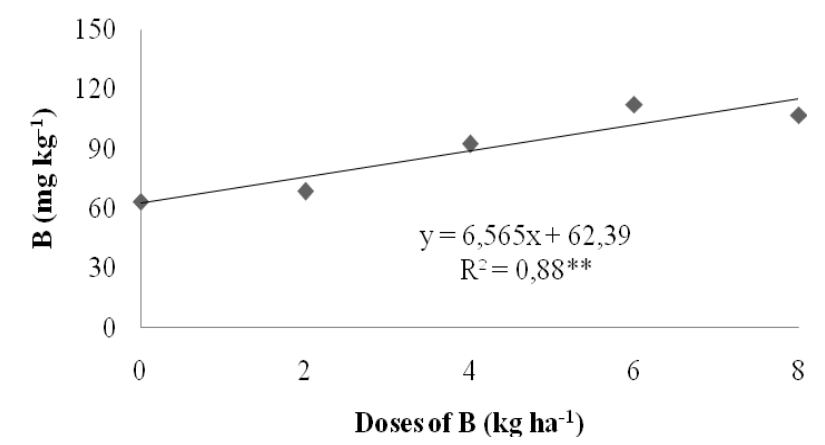

Fig 1. Contents of B in leaf depending on the B doses (a) without poultry litter, and (b) and application in broccoli culture. IpameriGO, 2016

Table 2. Boron content in the broccoli inflorescence, leaves and stems. Ipameri-GO, 2016.

\begin{tabular}{cccc}
\hline & Inflorescence & Leaves & Stems \\
\hline Doses of PL & & $\mathrm{mg} \mathrm{kg}^{-1}$ & 70.6 \\
$\left(\mathrm{t} \mathrm{ha}^{-1}\right)$ & 66.46 & $73.53 \mathrm{~b}$ & 72.2 \\
0 & 63.47 & $88.67 \mathrm{a}$ & 24.28 \\
\hline $\mathrm{CV}(\%)$ & 16.11 & 22.03 & \\
\hline
\end{tabular}

Averages followed by the same letter in the column do not differ by Tukey test, with $1 \% \leq \mathrm{p} \leq 5 \%$. PL: Poultry litter. CV (\%): coefficient of variation 
(a)

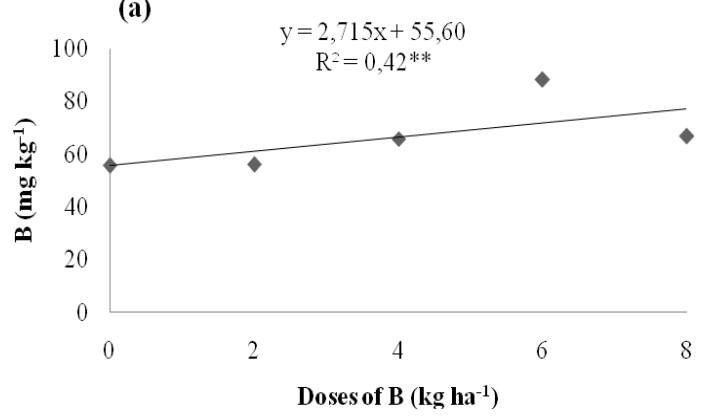

(b)

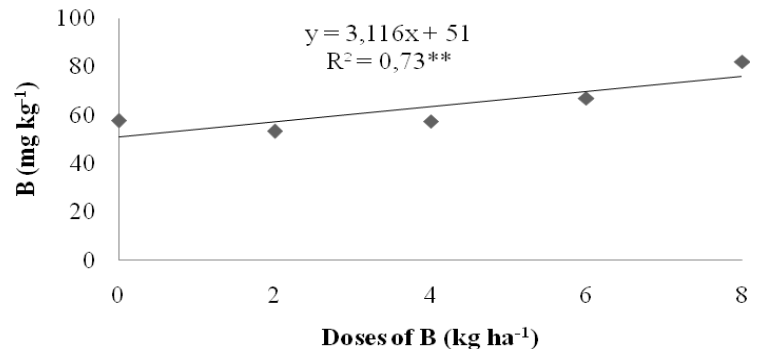

Fig 2. Contents of B in the inflorescences depending on the B doses (a) without poultry litter, and (b) and application in broccoli culture. Ipameri-GO, 2016.

Table 3. Commercial yield, gross revenue (GR) and gross revenue - B application costs (GR-C) of broccoli. Ipameri-GO, 2016.

\begin{tabular}{cccc}
\hline Doses of PL & Yield & GR & GR-C \\
\hline$\left(\mathrm{t} \mathrm{ha}^{-1}\right)$ & $\mathrm{kg} \mathrm{ha}^{-1}$ & $12036.65 \mathrm{~b} \$ \mathrm{ha}^{-1}$ & 11984.01 \\
0 & $19783 \mathrm{~b}$ & $13221.05 \mathrm{a}$ & 12812.40 \\
\cline { 3 - 4 } 10 & $21730 \mathrm{a}$ & & 12172.82 \\
${\mathrm{~B}\left(\mathrm{~kg} \mathrm{ha}^{-1}\right)}_{0}$ & 12350.81 & 12241.96 \\
2 & 20299 & 12465.70 & 12140.72 \\
4 & 20488 & 12377.83 & 12803.29 \\
8 & 20344 & 13053.88 & 12632.25 \\
\hline $\mathrm{CV}(\%)$ & 21455 & 12896.06 & 11.17 \\
\hline
\end{tabular}

Averages followed by the same letter in the column do not differ by Tukey test, with $1 \% \leq \mathrm{p} \leq 5 \%$. PL: Poultry litter. CV (\%): coefficient of variation

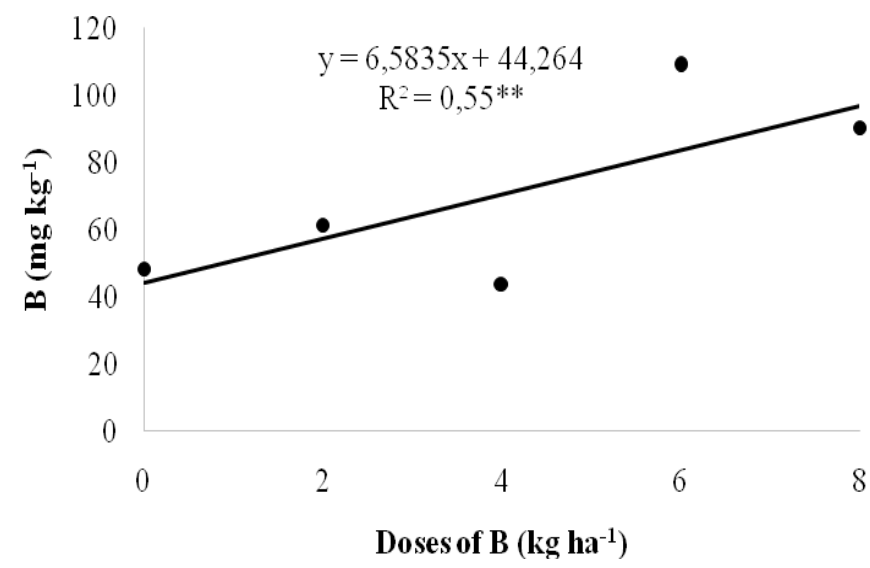

Fig 3. Content of B stem depending on the doses of B without poultry litter application in broccoli culture. Ipameri-GO, 2016. 

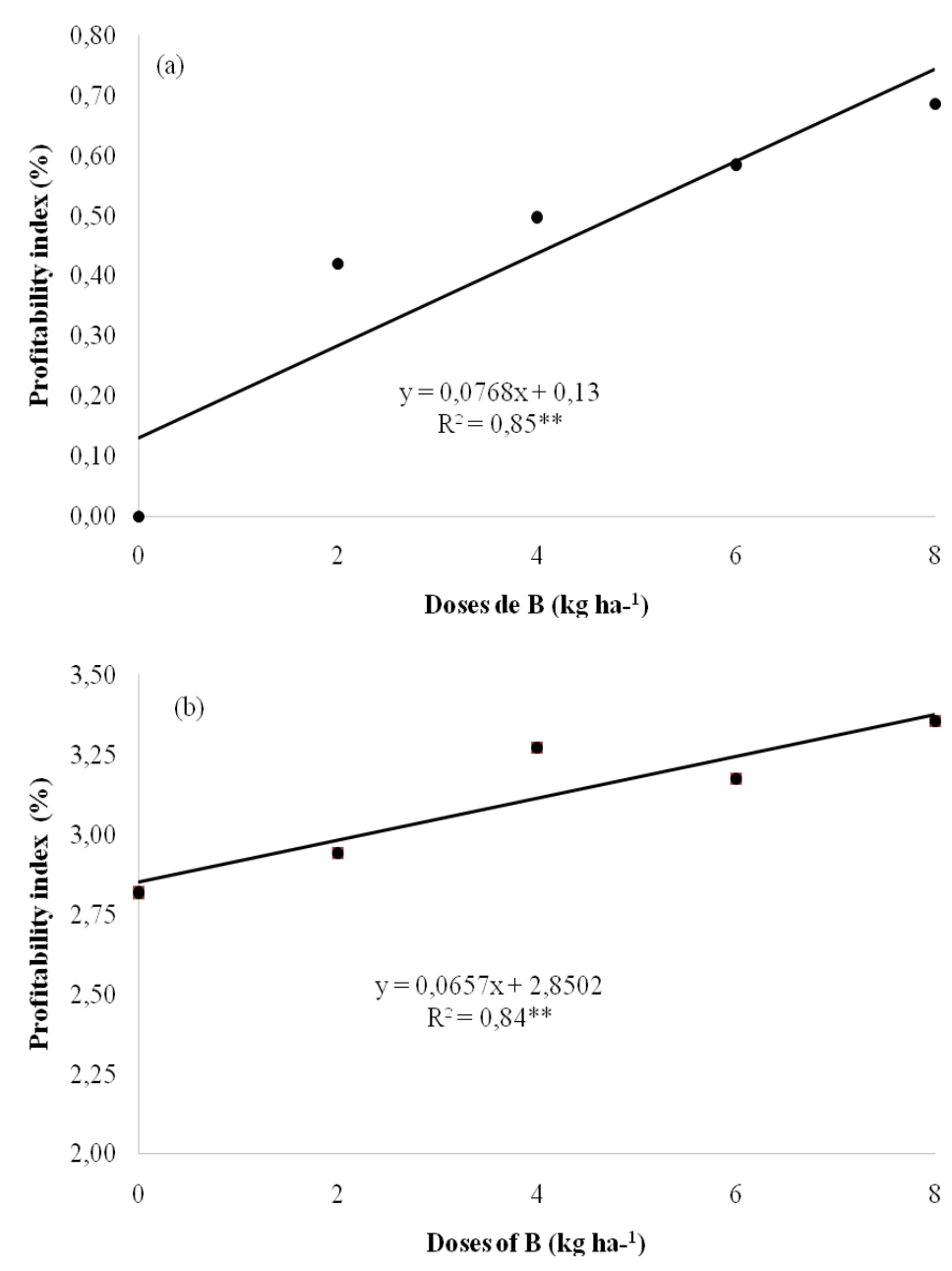

Fig 4. Profitability index (PI) depending on the B doses without poultry litter (A) and application (B) in the broccoli crop. IpameriGO, 2016.

However, we found that the highest yield values and the largest gross revenue were sufficient to promote greater economic return. We found a significant linear correlation between the $\mathrm{B}$ dose applied to the soil in the presence or absence of poultry litter and the profitability index (PI). The 8 $\mathrm{kg} \mathrm{ha}^{-1} \mathrm{~B}$ dose without poultry litter promoted a PI of $0.74 \%$, which represented a $0.61 \%$ increase relative to the control treatment (Fig 4a). The use of a dose up to $8 \mathrm{~kg} \mathrm{ha}^{-1} \mathrm{~B}$ with the application of $10 \mathrm{t} \mathrm{ha}^{-1}$ poultry litter resulted in a profitability index of $3.37 \%$, which was $3.24 \%$ greater than the control treatment IR and promoted the greatest financial return for the broccoli crop in this work (Fig 4b).

As observed, the increase in the B dose was not sufficient to present significant differences in most of the evaluated variables even at the low B levels found in the soil in the experiment. The plants also showed no visible signs of B toxicity. The findings contrast with the findings of Compagnol et al. (2009), who worked with broccoli in soils with a good level $\left(0.84 \mathrm{mg} \mathrm{dm}^{-3}\right)$ of B and found symptoms of $\mathrm{B}$ toxicity in plants exposed to the 0 to $8 \mathrm{~kg} \mathrm{ha}^{-1} \mathrm{~B}$ doses with a decreased yield.

Overall, the use of poultry litter promoted higher results for most variables. Fertilization with poultry litter usually contributed to improvement of the chemical, physical and biological characteristics of the soil (Kiehl, 2010). Despite the low B content present in the poultry litter, its use added approximately $2 \mathrm{~kg} \mathrm{ha}^{-1} \mathrm{~B}$, which possibly contributed directly to the increase in the leaf B levels, broccoli yield and profitability index.

\section{Materials and Methods}

\section{Plant materials}

The broccoli cultivar used was the single head Avenger cultivar (Sakata $\left.{ }^{\circledR}\right)$, which is recommended for mid-season planting. Sowing was performed on April 12, 2015, in 200cell polystyrene trays filled with an organomineral substrate (Plantmax® hortaliças). The plants were kept in a protected environment with $60 \%$ shading and irrigated daily using a micro sprinkler irrigation system.

\section{Experimental site}

The experiment was developed in the Ipameri, state of Goiás (GO), Brazil, at the geographical coordinates $17^{\circ} 43^{\prime} 19^{\prime \prime} \mathrm{S}$ and $48^{\circ} 08^{\prime} 51^{\prime \prime} \mathrm{W}$ at an altitude of $791 \mathrm{~m}$. According to the Köppen classification, the climate of the region is type Aw, which is defined as a tropical warm sub-humid climate with an average annual precipitation of $1450 \mathrm{~mm}$, a rainy season in the summer and a dry season in the winter. The average 
temperature in the region during the experiment ranged between 11 and $33{ }^{\circ} \mathrm{C}$.

\section{Experimental procedure and treatments}

The experimental design used was randomized blocks in a 2 x 5 factorial arrangement with three replicates. The first factor was fertilization without or with poultry litter ( 0 and 10 $\left.\mathrm{t} \mathrm{ha}^{-1}\right)$, and the second factor consisted of the foliar application of five doses of $\mathrm{B}\left(0,2,4,6\right.$ and $\left.8 \mathrm{~kg} \mathrm{ha}^{-1}\right)$ in the form of boric acid $(17 \% \mathrm{~B})$. The plots consisted of four 2.25 $\mathrm{m}$ rows, with $1.0 \mathrm{~m}$ spacing between the rows and $0.45 \mathrm{~m}$ spacing between the plants, for a total of 20 plants per plot. The 6 central plants were considered the usable area.

The study was conducted in a Dystrophic Red-Yellow Latosol (Oxisol) (Santos et al., 2013) with the following chemical characteristics: $4.6 \mathrm{cmol}_{\mathrm{c}} \mathrm{dm}^{-3} \mathrm{CEC} ; 78 \mathrm{~V} \% ; 17 \mathrm{~g}$ $\mathrm{dm}^{-3}$ organic matter; 2.4, 0.9 and $0.0 \mathrm{cmol}_{\mathrm{c}} \mathrm{dm}^{-3} \mathrm{Ca}, \mathrm{Mg}$ and $\mathrm{Al}$, respectively; 99, 3.6, 3.6, 0.71, 0.11, 0.13, 68, and 14.5 $\mathrm{mg} \mathrm{\textrm {dm } ^ { - }}{ }^{3} \mathrm{~K}, \mathrm{P}$ Mehlich, $\mathrm{S}, \mathrm{Zn}, \mathrm{B}, \mathrm{Cu}, \mathrm{Fe}$, and $\mathrm{Mn}$, respectively; and a medium soil texture.

The seedlings were transplanted to the field 25 days after emergence. Fertilization was performed 10 days before transplanting the seedlings following the recommendations for the crop proposed by Ribeiro et al. (1999). The macronutrient sources used were urea $(46 \% \mathrm{~N})$, ammonium single superphosphate $\left(03 \% \mathrm{~N}, 17 \% \quad \mathrm{P}_{2} \mathrm{O}_{5}\right)$ and potassium chloride $\left(60 \% \mathrm{~K}_{2} \mathrm{O}\right)$.

The $\mathrm{B}$ doses used for the soil application were diluted in 10 liters of water and applied in the area of the plots when transplanting the seedlings. The poultry litter fertilization was applied by broadcasting 30 days before transplanting the seedlings and was incorporated into the soil with hoes. The poultry litter dose was calculated and adjusted using the dry basis $\left(65^{\circ} \mathrm{C}\right)$ of the poultry litter as a reference. The chemical analysis of the $5^{\text {th }}$ batch of poultry litter ( 5 cycles of poultry) presented the following values: $24,76,19.5,410$, and $260 \mathrm{~g}$ $\mathrm{kg}^{-1} \mathrm{~N}, \mathrm{P}_{2} \mathrm{O}_{5}, \mathrm{~K}_{2} \mathrm{O}$, organic matter, and moisture, respectively; $200 \mathrm{mg} \mathrm{kg}^{-1} \mathrm{~B} ; 7.35 \mathrm{pH}$ and $13.4 \mathrm{C} / \mathrm{N}$ ratio.

Weed control was performed through manual weeding, and the remaining crop management, plant health and pest control measures recommended for the crop were performed as needed.

The irrigations were performed on alternate days in all plots, with an irrigation depth of $14 \mathrm{~mm}$ using a conventional micro sprinkler irrigation system and a total of approximately $270 \mathrm{~mm}$ of accumulated water during the cycle. Irrigation was interrupted when rainfall occurred, for a total accumulated precipitation of $405 \mathrm{~mm}$ throughout the entire broccoli crop cycle.

\section{Measurements}

The harvest took place from 58 to 70 days after transplanting (DAT) the seedlings, when the inflorescences were well formed and compact but before flowering. The production components were evaluated in six plants from the useful area of each plot. The following parameters were assessed: fresh and dry masses of the inflorescences, leaves and stem; the inflorescence diameter; and the incidence of hollow stem disorder.

A high-precision electronic scale was used to determine the fresh mass of the different plant parts, which were placed in a forced air oven at a temperature of $65^{\circ} \mathrm{C}$ for 72 hours to obtain the dry mass. The cross-sectional diameter of the inflorescences was measured using a $30-\mathrm{cm}$ graduated ruler. The total and commercial yields $\left(\mathrm{kg} \mathrm{ha}^{-1}\right)$ were estimated through extrapolation of the result obtained in the useful area of the plot to one hectare.

The commercial yield was obtained following the cauliflower classification standards proposed by Hortibrasil (2015) in which commercial inflorescences were those without mechanical injuries or diseases and with a fresh mass greater than $0.5 \mathrm{~kg}$.

The B analysis was conducted in the inflorescence, leaves and stem in the same samples used to obtain the dry mass. The material was ground in a Wiley mill with a 1-mm mesh size. The samples were subjected to dry digestion, and the B content in the plant was determined using the azomethine $\mathrm{H}$ colorimetric method (Silva, 2009).

Economic aspects were evaluated through the average price of broccoli, fertilizers and poultry litter during the period from 2010 to 2015 . For broccoli, the price (US\$ 1.00 equal to $\mathrm{R} \$ 3.09$ from April to July 2015) was US\$ $0.60 \mathrm{~kg}^{-1}$ (Ceasago, 2015), whereas the price of boric acid was US\$ $6.70 \mathrm{~kg}^{-1}$ (IEA, 2015) and the price of a ton of poultry litter was US\$ 32.36 (price charged in the region of Ipameri-GO). Moreover, the operational price for each application was US\$ 32.36 for the application of poultry litter and the soil application (prices of the region). The cultivation costs were the same for all treatments and were not used for the calculations. The gross revenue (GR), gross revenue - B application costs (GR-C) and profitability index (PI) were also calculated.

\section{Data analysis}

The data were subjected to analysis of variance by the $\mathrm{F}$ test $(0.01 \leq p \leq 0.05)$, and the $\mathrm{B}$ doses were subjected to regression analysis. The best models were chosen based on the coefficient of determination and its significance using Sisvar software (Ferreira, 2008).

\section{Conclusion}

The poultry litter, on the average of all doses, increased the foliar B levels and the fresh mass of the inflorescences and leaves of the broccoli, providing a greater yield and gross revenue. The $B$ levels in the inflorescences and leaves increased with the $\mathrm{B}$ doses regardless of the fertilization with poultry litter. However, the B levels in the stem only increased in the absence of organic fertilizer.

The profitability index increased with doses up to $8 \mathrm{~kg} \mathrm{ha}^{-1} \mathrm{~B}$ both in the presence and absence of fertilization with poultry litter.

\section{Acknowledgments}

In the Foundation to Support the State of Goiás Research (FAPEG), Federal Institute Goiano (IF Goiano) for financial support. At the State University of Goiás (UEG) for support in carrying out the project. The authors thank the UEG for providing fellowships (PROBIP 2016) to the last author.

\section{References}

Bergamin LG, Cruz MCP, Ferreira ME, Barbosa JC (2005) Cabbage yield in relation to boron fertilization associated with organic manure. Hort Bras. 23:311-315.

Blum LEB, Amarante CVT, Güttler G, Macedo AF, Kothe DM, Simmler AO, Prado G, Guimarães LS (2003) Production of squash and cucumber in soil amended with poultry manure and pine bark. Hort Bras. 21:627-631. 
Camargo MS, Mello SC, Foltran DE, Carmello QAC (2009) Yield and incidence of hollow stem disorder of cauliflower 'Sharon' influenced by the application of nitrogen and boron. Hort Bras. 27:030-034.

Capone A, Dario AS, Menegon MZ, Fidelis RR, Barros HB (2016) Responses of sunflower cultivars to increasing doses of boron in the between harvests the Cerrado Tocantinense. Rev Ver Agroec Des Sust. 11:43-48.

Carneiro IF, Almeida Neto JX, Naves RV, Chaves LJ (1995) Effects of different borax rates and manure on cabbage (Brassica oleracea var. capitata) crop. Anais Esc de Agron e Vet. 25:1-11.

Ceagesp - Companhia de Entrepostos e Armazéns Gerais de São Paulo (2016). 10 de janeiro. Comunicados 2007. Disponível em http://www.ceagesp.gov.br/comunicacao/.

Ceasago - Centrais de Abastecimento do Estado de Goiás. Disponível. (2015) 10 de dezembro. Conjuntura anual. Disponível http://www.ceasa.goias.gov.br/post/ver/145124/analiseconjuntural-anual/.

Compagnol R, Nicolai M, Mello SC, Abrahão C, Barbosa JC (2009) Boron and nitrogen on hollow stem and yield of broccoli. Ciênc Agrotec. 33:1477-1485.

Ferreira DF (2008) SISVAR: um programa para análises e ensino de estatística. Rev Cient Symposium. 6: 36-41.

Filgueira FAR (2013) Novo manual de olericultura. Viçosa: UFV. 421p.

Gupta UC (1983) Boron deficiency and toxicity symptoms for several crops as related to tissue boron levels. J Plant Nutr. 6:387-395.

Hortibrasil - Intituto brasileiro de qualidade em hortaliças. (2015) 10 de dezembro. Disponível em http://www.hortibrasil.org.br/jnw/classificacao/couveflor/ar quivos/categoria.html/

IEA - Instituto de Economia Agrícola. (2015) 15 de dezembro. Área e produção dos principais produtos da agropecuária do estado de São Paulo. Disponível em http://www.iea.sp.gov.br/out/banco/menu.php/.
Kiehl EJ (2010) Novo fertilizantes orgânicos. Piracicaba: Agronômica Ceres. 248p.

Lalla JG, Laura VA, Rodrigues APDC, Seabra Júnior S, Silveira DS, Zago VH, Dornas MF (2010) Competição de cultivares de brócolos topo cabeça única em Campo Grande. Hort bras. 28:260-363.

Melo RAC, Madeira NR, Peixoto JR (2010) Single head broccoli cultivars production in summer under no-tillage. Hort bras. 28:23-28.

Mueller S, Wamser AF, Suzuki A, Becker WF (2013) Tomato yield under organic fertilization and supplementation with mineral fertilizers. Hort bras. 31:8692.

Nable RO, Bañuelos GS, Paull JG (1997) Boron toxicity. Plant Soil. 193:181-198.

Pizetta LC, Ferreira ME, Cruz MCP, Barbosa JC (2005) Response of boron fertilization on broccoli, cauliflower and cabbage planted in sandy soil. Hort bras. 23:51-56.

Ribeiro AC, Guimarães PTG, Alvarez VVH (1999) Recomendações para o uso de corretivos e fertilizantes em Minas Gerais: $5^{\text {a }}$ aproximação. Viçosa: Comissão de Fertilidade do solo do Estado de Minas Gerais. 360p.

Rosolém CA, Bíscaro T (2007) Boron adsorption and leaching in a Brazilian Oxisol. Pesq Agropec Bras. 42:1473-1478.

Santos HG, Jacomine PKT, Anjos LHC, Oliveira VA, Lumbreras JF, Coelho MR, Almeida JA, Cunha TJF, Oliveira JB (2013) Sistema brasileiro de classificação de solos. 3.ed. rev. e ampl. Brasília: Embrapa, 353p.

Silva FC (2009) Manual de análises químicas de solos, plantas e fertilizantes. 2.ed. Distrito Federal: Brasilia, 627p.

Souza JL, Resende P (2003) Manual de horticultura orgânica.Viçosa: Aprenda Fácil. 564 p.

Valadão FCA, Maas KDB, Weber OLS, Júnior DDV, Silva TJ (2011) Variation in soil properties by management systems with application of poultry litter. Rev Bras Ci Solo. 35:2073-2082. 